ISSN: 2757-6485

$2021 \& 2(1)$

\title{
Examination of Physical Competence Tests of Member Countries of the International Association of Gendarmeries and Police Forces with Military Status and a Model Proposal for Turkey
}

\section{Merve CiN ${ }^{1} \quad \& \quad$ Nazif SAVRAN $^{2} \quad \& \quad$ Refik ÇABUK $^{3}$}

\section{RESEARCH ARTICLE}

\section{History}

Received: 18 March 2021

Accepted: 10 April 2021

Published: 16 April 2021

DOI: http://dx.doi.org/10.29228/anatoliasr.7

\section{Authors Communications}

1- (Corresponding Author) Department of Physical Education and Sports, Gendarmerie and Coast Guard Academy, Ankara, Turkey mervecin_11@hotmail.com https://orcid.org/0000-0001-9408-7853

2- Department of Physical Education and Sports, Gendarmerie and Coast Guard Academy, Ankara, Turkey

3- Department of Coaching Education, School of Physical Education and Sports, Bayburt University, Bayburt, Turkey

refikcabuk@bayburt.edu.tr

https://orcid.org/0000-0002-3682-3135

\section{Acknowledgement}

All authors contributed to the conception and design of the study.

Funding

This study received no specific financial support.

Competing Interests

The authors declare that they have no conflict of interests.

Transparency

The authors confirm that the manuscript is an honest, accurate, and transparent account of the study was reported; that no vital features of the study have been omitted; and that any discrepancies from the study as planned have been explained.

Ethical

This study follows all ethical practices during writing.

Citation

Cin, M., Savran N., Cabuk, R. (2021). Examination of Physical Competence Tests of Member Countries of the International Association of Gendarmeries and Police Forces with Military Status and a Model Proposal for Turkey, Anatolia Sport Research, 2(1): 8-15.

Copyright $(\mathcal{C} 2020$ by Anatolia Sport Research

\section{ABSTRACT}

Aim: This study aimed to evaluate the physical competence tests used in the recruitment of Gendarmerie personnel in the member countries of the International Association of Gendarmeries and Police Forces with Military Status (FIEP) and propose an physical competence test for Turkey Material and Method: The physical competence tests employed by the countries within the FIEP in the recruitment of the Gendarmerie personnel were obtained from the official websites of the relevant countries. The frequency distribution and percentage of physical competence tests divided into four different categories were calculated using the statistical analysis program SPSS 21.0 for WINDOWS ${ }^{\odot}$.

Results: It has been determined that most countries use multiple physical competence tests under at least two categories of physical competence tests. $83.3 \%$ of the countries prefer physical competence tests based on endurance, $66.7 \%$ sprint/power, $83.3 \%$ muscle strength endurance and $25 \%$ coordination/skill/balance biomotor abilities in the recruitment of gendarmerie personnel. It was determined that $91.7 \%$ of 12 countries prefer three or more physical competence tests. It was observed that $50 \%$ of the countries chose three out of four different physical test categories, and $33 \%$ chose two different physical test categories.

Conclusion: It is required that an ideal gendarmerie officer has aerobic endurance, anaerobic power, muscular strength, balance, coordination, agility and flexibility to execute their duties. Due to a large number of applications for the recruitment of the gendarmes, the accommodation needs of the candidates and economic reasons, the physical competence tests need to be carried out in a limited time frame. Thus, testing all seven physical abilities separately may not be applicable. It may be more appropriate to test physical fitness elements that are relevant when executing tasks that are more frequently encountered by the Gendarmerie. As a result of our study, we recommend the Turkish Gendarmerie to measure the coordination course endurance and strength capabilities. It is seen that the candidate will be eligible for a coordination course related to duties that the Gendarmerie may encounter, running distances between $1000 \mathrm{~m}$ and $3000 \mathrm{~m}$ for endurance and pull-up or push-up test for strength.

Keywords: Endurance, Gendarmerie, Physical Competence Tests, Strength 


\section{INTRODUCTION}

Increasing terrorism, crime and violence-like incidents around the world in recent years have increased the need and demand for public safety (House, 2015). While a large percentage of a law enforcement agency's time on duty is spent on sedentary occupations, a high level of physical fitness remains necessary to effectively respond to many incidents (Bonneau et al., 1995). While performing their duties, they may need to move quickly in a coordinated manner, run short or long distances, jump, crawl, use balance, engage in combat, climb, lift heavy weights, push or pull (Bock et al., 2016). For this reason, public security personnel (security forces) such as military, police and gendarmerie need a high level of physical, mental and technical readiness to deal with and prevent terrorism, smuggling, crimes against property or violent incidents (Marins et al., 2020) and a higher physical capacity and ability than civilians (Sherrard et al., 2004). The ability of security personnel to successfully execute their daily tasks is closely related to their high level of physical performance (Knapik et al., 2006; Pope et al., 1999; Sherrard et al., 2004). Conversely, an insufficient physical performance level may result in a failure to execute tasks successfully and, as a result, put the public safety in jeopardy (Dawes et al., 2016 and 2017; Shusko et al., 2017). Currently, several research groups have emphasized that the physical performance level is directly related to the injury risk and job performance of the officers (Evans et al., 2005; Knapik et al., 2003; Pope et al., 1999). Hence, tests measuring physical performance in security force personnel recruitment are considered as a crucial criterion in officer recruitment worldwide. A physical test or physical competence tests including physical abilities that are crucial in performing the duties or tasks of military or law enforcement personnel is of key importance in the recruitment of the right personnel (Taylor et al., 2016). The recruitment of law enforcement personnel with the required physical conditions through correctly selected physical competence tests contributes significantly to the protection and maintenance of public safety. In this context, physical performance tests used in the recruitment of soldiers and police officers have been widely studied by different research groups. As a result of the literature review, no studies evaluating the physical competence tests used in the recruitment of the gendarmerie officers were found. The disregard for an assessment specific to the physical competence tests used in the recruitment of gendarmerie personnel may be due to the fact that the Gendarmerie organization is quite limited compared to the military and police organizations worldwide. Whether the physical competence tests used in Gendarmerie recruitment are sufficient enough to meet the physical abilities that include the duties and difficulties that the Gendarmerie personnel will encounter in their professional life is a matter of curiosity. Thus, this study aimed to evaluate the physical competence tests used in the recruitment of Gendarmerie personnel in the member countries of the International Association of Gendarmeries and Police Forces with Military Status (FIEP) and propose an physical competence test for Turkey.

\section{MATERIAL AND METHOD}

\section{Research Model}

Qualitative research method was used in this study.

\section{Research Group}

This review study examined the physical competence tests used in the recruitment of Gendarmerie personnel in countries that are members of the FIEP. In this study, the physical competence tests used by Turkey, France, Italy, Spain, Portugal, Netherlands, Romania, Argentina, Chile, Brazil, Ukraine and Senegal which are member countries in the recruitment of gendarmerie personnel in 2019-2020 were evaluated. 


\section{Data Collection Method}

The physical competence tests employed by the countries within the FIEP in the recruitment of the Gendarmerie personnel were obtained from the official websites of the relevant countries. Physical competence tests used in the recruitment of the Gendarmerie personnel belonging to 12 of 19 FIEP member countries were accessed. The remaining 7 countries could not be included in the study because they did not share physical testing methods on their official internet addresses. Physical competence tests were examined in four different categories according to their types. Long-term tests dominated by the aerobic energy system were evaluated in the aerobic endurance category, short-term tests in which phosphogen systems were used predominantly in the sprint/power category, tests that include maintaining the strength for a long time in the muscle strength endurance category, and tests including coordination skills and balance aiding abilities in the coordination/skill/balance category.

\section{Statistical Analysis}

The frequency and percentage distributions of physical competence tests divided into four different categories were calculated using the statistical analysis program SPSS 21.0 for WINDOWS ${ }^{\circ}$.

\section{RESULTS}

Table 1. Physical competence tests performed by countries in the recruitment of Gendarmerie personnel

\begin{tabular}{|c|c|c|c|c|}
\hline $\begin{array}{l}\text { Countries and } \\
\text { References }\end{array}$ & Endurance & Sprint/ Power & $\begin{array}{l}\text { Muscular strength } \\
\text { and endurance }\end{array}$ & $\begin{array}{l}\text { Coordination } \\
\text { /Ability / Balance }\end{array}$ \\
\hline $\begin{array}{l}\text { Gendarmerie, Turkey, } \\
2021\end{array}$ & & & & Coordination test \\
\hline $\begin{array}{l}\text { Gendarmerie } \\
\text { Nationale, France, } 2021\end{array}$ & & & $\begin{array}{l}\text { Muscular strength } \\
\text { test including the } \\
\text { simulation and } 15 \mathrm{~m} \\
\text { weight bearing }\end{array}$ & Obstacle course \\
\hline $\begin{array}{l}\text { Arma dei } \\
\text { Carabinieri, Italy, } 2021\end{array}$ & $1000 \mathrm{~m}$ run & $\begin{array}{l}\text { High jump and long } \\
\text { jump }\end{array}$ & $\begin{array}{l}\text { Push-up and Pull-up } \\
\text { test }\end{array}$ & \\
\hline $\begin{array}{l}\text { Guardia Civil, Spain, } \\
2021\end{array}$ & $1000 \mathrm{~m}$ run & $\begin{array}{l}50 \mathrm{~m} \text { run and } 50 \mathrm{~m} \\
\text { swim }\end{array}$ & Push-up & \\
\hline $\begin{array}{l}\text { Guarda Nacional } \\
\text { Republicana, Portugal, } \\
2021\end{array}$ & Cooper test & $\begin{array}{l}\text { Jumping over the } \\
\text { wall without } \\
\text { support, standing } \\
\text { long jump }\end{array}$ & $\begin{array}{l}\text { Sit-up and Pull-up } \\
\text { test }\end{array}$ & $\begin{array}{l}\text { Walking in balance } \\
\text { on a high wall }\end{array}$ \\
\hline $\begin{array}{l}\text { Koninklijke } \\
\text { Marechaussee, The } \\
\text { Netherlands, } 2021\end{array}$ & Cooper test & & $\begin{array}{l}\text { Sit-up, Push-up and } \\
\text { Pull-up test }\end{array}$ & \\
\hline $\begin{array}{l}\text { Jandarmeria, Romania, } \\
2021\end{array}$ & $1000 \mathrm{~m}$ run & $\begin{array}{l}50 \mathrm{~m} \text { run, Medicine } \\
\text { ball throwing }\end{array}$ & & \\
\hline $\begin{array}{l}\text { Gendarmeria Nacional, } \\
\text { Argentina, } 2021\end{array}$ & $1500 \mathrm{~m}$ run & $\begin{array}{l}25 \mathrm{~m} \text { technical } \\
\text { swimming, } 25 \mathrm{~m} \\
\text { non-technical } \\
\text { swimming }\end{array}$ & $\begin{array}{l}\text { Sit-up, Push-up and } \\
\text { Pull-up test }\end{array}$ & \\
\hline Carabineros, Chile, 2021 & 6 minute run test & $50 \mathrm{~m}$ run & Sit-up, Push-up test & \\
\hline $\begin{array}{l}\text { National Council of the } \\
\text { General Commanders of } \\
\text { the military Police and } \\
\text { military Fire corps, } \\
\text { Brazil, } 2021\end{array}$ & Cooper test & & $\begin{array}{l}\text { Sit-up, Push-up and } \\
\text { Pull-up test }\end{array}$ & \\
\hline $\begin{array}{l}\text { National Guard, Ukraine, } \\
2021\end{array}$ & $1 \mathrm{~km}$ and $3 \mathrm{~km}$ run & $\begin{array}{l}100 \mathrm{~m} \text { and } 10 \times 10 \mathrm{~m} \\
\text { run }\end{array}$ & $\begin{array}{l}\text { Sit-up, Push-up and } \\
\text { Pull-up test }\end{array}$ & \\
\hline $\begin{array}{l}\text { Gendarmerie } \\
\text { Nationale, Senegal, } 2021\end{array}$ & $1000 \mathrm{~m}$ run & $\begin{array}{l}100 \mathrm{~m} \text { run, long } \\
\text { jump and high jump, } \\
\text { Shot put }\end{array}$ & Climbing rope & \\
\hline
\end{tabular}

The physical competence tests used by 12 FIEP member countries in the recruitment of Gendarmerie personnel are shown in detail in Table 1. It was observed that only one country (Turkey) preferred a single physical test category while one country (Portugal) used physical competence tests 
belonging to all physical test categories (Table 1). It has been determined that most countries use multiple physical competence tests under at least two categories of physical competence tests (Table 1).

Table 2. Frequency of use of physical competence tests by countries under four different categories

\begin{tabular}{lcccc}
\hline & Endurance & Sprint/ Power & $\begin{array}{c}\text { Muscular strength } \\
\text { and endurance }\end{array}$ & $\begin{array}{c}\text { Coordination } \\
\text { /Ability / Balance }\end{array}$ \\
\hline Absolute Frequency & 10 & 8 & 10 & 3 \\
\hline Relative Frequency & $83.3 \%$ & $66.7 \%$ & $83.3 \%$ & $25 \%$ \\
\hline
\end{tabular}

Countries preferred physical competence tests including $83.3 \%$ of the endurance, $66.7 \%$ sprint/power, $83.3 \%$ muscle strength endurance and $25 \%$ coordination/skill/balance biomotor abilities in the recruitment of gendarmerie personnel (Table 2).

Table 3. The percentage of the number of physical competence tests performed in different categories and the percentage of the total number of physical competence tests used in the four categories

\begin{tabular}{lccccc}
\hline Endurance & $\begin{array}{c}\text { Sprint/ } \\
\text { Power }\end{array}$ & $\begin{array}{c}\text { Muscular strength } \\
\text { and endurance }\end{array}$ & $\begin{array}{c}\text { Coordination } \\
\text { /Ability / Balance }\end{array}$ & $\begin{array}{c}\text { Number of } \\
\text { Total Test }\end{array}$ \\
\hline No Test & $16.7 \%$ & $33.3 \%$ & $16.7 \%$ & $75 \%$ & \\
\hline 1 test & $75 \%$ & $16.7 \%$ & $16.7 \%$ & $25 \%$ & - \\
\hline 2 test & $8.3 \%$ & $41.7 \%$ & $33.3 \%$ & & $16.7 \%$ \\
\hline 3 test & - & - & $33.3 \%$ & $33.3 \%$ \\
\hline 4 test & - & $8.3 \%$ & - & $16.7 \%$ \\
\hline 5 test & - & - & - & $167 \%$ \\
\hline 6 test & - & - & - & $8.3 \%$ \\
\hline 7 test & - & - & - & & \\
\hline
\end{tabular}

It was determined that $91.7 \%$ of 12 countries (11 countries) preferred three or more physical competence tests (Table 3 ).

Table 4. Absolute and relative frequencies of countries testing how many of the four physical fitness categories

\begin{tabular}{lcccc}
\hline & $\begin{array}{c}\text { Number of } \\
\text { countries testing } \\
\text { one of the four } \\
\text { categories }\end{array}$ & $\begin{array}{c}\text { Number of } \\
\text { countries } \\
\text { testing two of } \\
\text { the four } \\
\text { categories }\end{array}$ & $\begin{array}{c}\text { Number of countries } \\
\text { testing three of the } \\
\text { four categories }\end{array}$ & $\begin{array}{c}\text { Number of countries } \\
\text { testin all four } \\
\text { categories }\end{array}$ \\
\hline Absolute Frequency & 1 country & 4 country & 6 country & 1 country \\
\hline Relative Frequency & $8.3 \%$ & $33.3 \%$ & $50 \%$ & $8.3 \%$ \\
\hline
\end{tabular}

It was observed that $50 \%$ of the countries chose three out of four different physical test categories, and 33\% chose two different physical test categories (Table 4).

\section{DISCUSSION AND CONCLUSION}

The aim of our study is to comprehensively evaluate the physical competence tests used in the recruitment of Gendarmerie personnel in the member countries of the International Association of Gendarmeries and Police Forces with Military Status (FIEP) and propose an physical competence test for Turkey. Our main results show that 10 out of 12 countries apply two or three of the four categories of physical competence tests regarding their duties. Among the 12 countries, it is observed that only one country recruits gendarmerie personnel using the coordination test belonging to the single physical fitness category (coordination/skill/balance category). However, Gendarmerie personnel also need aerobic endurance, sprint/power, muscle strength endurance while performing their duties (Marins et al., 2019). 8 out of 10 countries that utilize tests measuring aerobic endurance competence prefer $1000 \mathrm{~m}$ and Cooper tests. The gold standard method of measuring aerobic endurance is the test protocol that determines the maximal oxygen consumption $\left(\mathrm{VO}_{2 \max }\right)$. Since measuring the $\mathrm{VO}_{2 \max }$ level directly 
requires quite expensive measuring instruments, many researchers have tried to determine the $\mathrm{VO}_{2 \max }$ level indirectly through tests such as the Cooper test, 1-mile or 1.5-mile (Sage and Loudermirk, 1979; Grant et al., 1995; Kayıhan et al., 2014). At running speeds or exercise intensities corresponding to maximal oxygen consumption, the duration of exhaustion varies between 3 and 10 minutes (Billat et al., 1995; Ozkaya et al., 2020). At running speeds corresponding to these periods, sub-elite athletes or physically active individuals can cover distances between $1000 \mathrm{~m}$ and $3000 \mathrm{~m}$. Therefore, running distances between $1000 \mathrm{~m}$ and $3000 \mathrm{~m}$ can be used to measure aerobic endurance. In addition, as the Cooper test has a high correlation with the $\mathrm{VO}_{2 \max }$ level and is considered valid, it can be used to measure endurance ability.

While a low aerobic endurance level is also closely associated with musculoskeletal injuries (Joseph et al., 2012) and chronic diseases (Knapik et al., 2001), a high muscle strength endurance capacity also plays a crucial role in reducing the risk of musculoskeletal injuries (Kraschnewski et al., 2016; Sarah et al., 2017). It is also closely related to the operational duties of law enforcement officers (Beck et al., 2015).

Our study results show that $83 \%$ of the countries (10 countries) prefer the muscle strength endurance tests. It has been determined that 8 of these countries measure the muscle strength endurance with the commonly tests such as sit-up, push-up and pull-up tests. Senegal (Gendarmerie Nationale, Senegal, 2021) and France (Gendarmerie Nationale, France, 2021) as the other two countries, seem to prefer a muscular strength test that includes a rope climbing test and simulation, respectively.

Muscular strength and muscular endurance play a crucial role when wearing heavy combat equipment and performing military tasks (J. Knapik et al., 2012). Hence, personnel with high muscle strength endurance may be more successful in executing operational tasks. 4 out of 10 countries that use muscle strength endurance tests use two, and the other 4 uses three tests. The main reason for the need for more than one test here may be due to the desire to measure the muscular strength of muscle groups of different body parts. If physical competence tests for the recruitment of gendarmerie personnel have to be carried out in a limited time period for some reason, it may be disadvantageous to perform multiple tests of only one skill. In this case, the parameters desired to be measured in tests of other physical abilities may not be measured validly and ii) the risk of musculoskeletal injury may increase in candidates. A more accurate approach may be to choose a single test with a large number of joints involved in movement to measure muscular strength and endurance in a limited time period. When we examine the tests used by countries in measuring muscular strength and endurance in terms of kinesiology, the sit-up test evaluates the core region, the push-up test evaluates the shoulder and chest area, and the pull-up test evaluates the strength and endurance of shoulder and back muscles. Push-up and pull-up tests can be preferred due to the disadvantages of the sit-up test and the criticisms made on it and the participation of fewer joints during the execution compared to push-up and pull-up movements. In addition, push-up and pull-up movements can be considered as simulations of the physical tasks faced by the gendarmerie.

Law enforcement officers need anaerobic power in missions such as short pursuit, escape-chase and jump-leap. Therefore, 8 out of 12 countries preferred physical competence tests belonging to the sprint/power category when recruiting gendarmerie personnel. There are differences in the anaerobic power tests selected between countries. It is striking that most of the countries that measure anaerobic power make an assessment with two or more tests. The main reason for this may be the evaluation of anaerobic power for the lower and upper extremities separately. While high jump, long jump, standing long jump, $50 \mathrm{~m}$ or $100 \mathrm{~m}$ sprint, $10 \times 10 \mathrm{~m}$ running test, unsupported jumping over a high wall test are used to measure anaerobic power of the lower extremity, medicine ball throwing, and shot put tests are used for the upper extremity. Apart from the tests generally used in the field, Chile (Carabineros, Chile 
2021). and Spain (Guardia Civil, Spain 2021) also preferred 25m and 50m swimming tests. These two countries, which have the longest beaches among the 12 countries we studied, may have needed to evaluate candidates' swimming performance in their physical competence tests due to having the longest beaches. It is known that all tests except the unsupported jump test over the wall have a high level of validity and reliability in measuring anaerobic power. No high fatigue occurs as a result of the use of multiple tests for anaerobic power measurement. Thus, the use of one anaerobic power test for both the lower and upper extremities may allow a more appropriate assessment.

When the four physical ability categories are examined, it is striking that the tests belonging to the coordination/skill/balance category are the least used. While only $25 \%$ of the total countries (three countries) use tests involving Coordination/Ability/Balance category, other countries disregard tests involving coordination. The low validity and reliability of coordination and obstacle courses, which test biomotor abilities such as balance and agility, can be seen as a reason for not being preferred. On the other hand, coordination and obstacle courses can also be created from activities related to physical fitness components needed by the law enforcement personnel. Coordination or obstacle courses can be used as they include the coordination, strength and balance required by the law enforcement personnel. Only, Turkey and France have used the coordination and obstacle course under the category of coordination. Additionally, Portugal aimed to measure balance ability with a different test apart from coordination and obstacle parkour. This test involves walking in balance on a high wall. While making physical test recruitments, minimizing the risk of injury and mutilation to the tests is considered as one of the most critical criteria. For these reasons, it may be more appropriate to use tests specific to balance, agility and flexibility, which have both low risk of injury and high validity and reliability. T-Drill or Illinois test for agility performance, flamingo or single leg balance test for balance performance and sitand-reach tests can be use for flexibility.

As a requirement of their work, law enforcement officers have physically demanding tasks, but gendarmes have military tasks in addition to civil and administrative tasks in countries such as Turkey, where the fight against terrorism is active. Turkish Gendarmerie personnel have to cover long distances with heavy equipment (helmets, backpacks, weapons, ammunition, communication devices and medical equipment) in order to perform high-risk missions. Due to the duties and responsibilities taken by the Turkish Gendarmerie, there is a need for physical fitness components that both police and military personnel need. Given all this, Turkey needs physical competence tests that measure candidates' strength and endurance ability, in addition to recruiting with a coordination test.

An ideal gendarmerie officer uses endurance, anaerobic power, muscular strength, balance, coordination, agility and flexibility while executing their duties. Due to the large number of applications for the recruitment of the gendarmes, the accommodation needs of the candidates and economic reasons, physical competence tests should be carried out in a limited time frame. Therefore, testing the seven physical abilities mentioned above separately may not be applicable due to circumstances. It may be more appropriate to test physical fitness components that are relevant when executing tasks which are more frequently encountered by the Gendarmerie. Because of the geographical structure, conditions and duties and responsibilities assigned to the gendarmerie affect the physical fitness components required by the Gendarmerie officers, these should be taken into account when selecting physical fitness tests.

As a result of our study, we recommend the Turkish Gendarmerie to measure the coordination course endurance and strength capabilities. It is seen that the candidate will be eligible for a coordination course related to duties that the Gendarmerie may encounter, running distances between $1000 \mathrm{~m}$ and $3000 \mathrm{~m}$ for endurance and pull-up or push-up test for strength. In this context, the Gendarmerie and Coast Guard Academy plans to shape the physical test contents of candidates in line with the recommendations. 


\section{REFERENCES}

Arma dei Carabinieri, Italy (2021, January 08). http://www.carabinieri.it/concorsi/area-concorsi

Beck, A. Q., Clasey, J. L., Yates, J. W., Koebke, N. C., Palmer, T. G. \& Abel, M. G. (2015). Relationship of Physical Fitness Measures vs. Occupational Physical Ability in Campus Law Enforcement Officers. The Journal of Strength \& Conditioning Research, 29(8), 2340-2350.

Berria, J., Daronco, L. S. E. \& Bevilacqua, L. A. (2011). Motor Fitness and Ability for The Work of Military Police of The Special Operations Battalion. Salusvita, 30(2), 89-104.

Billat, V., Renoux, J. C., Pinoteau, J., Petit, B. \& Koralsztein, J. P. (1995). Times To Exhaustion at 90,100 and $105 \%$ of Velocity at $\mathrm{VO} 2$ max (Maximal aerobic speed) and Critical Speed in Elite Longdistance Runners. Archives of Physiology and Biochemistry, 103(2), 129-135.

Blacker, S. D., Carter, J. M., Wilkinson, D. M., Richmond, V. L., Rayson, M. P. \& Peattie, M. (2013). Physiological Responses of Police Officers During Job Simulations Wearing Chemical, Biological, Radiological and Nuclear Personal Protective Equipment. Ergonomics, 56(1), 137-147.

Bock, C., Stierli, M., Hinton, B. \& Orr, R. (2016). The Functional Movement Screen as a Predictor of Police Recruit Occupational Task Performance. Journal of Bodywork and Movement Therapies, 20(2), 310-315.

Bonneau, J. \& Brown, J. (1995). Physical Ability, Fitness and Police Work. Journal of Clinical Forensic Medicine, 2(3), 157-164.

Carabineros, Chile

(2021,

January

04). https://html.gendarmeria.gob.cl/doc/escuela/admision_2017/Info_Ev_Fisica_GA2.pdf

Dawes, J. J., Lindsay, K., Bero, J., Elder, C., Kornhauser, C. \& Holmes, R. (2017). Physical Fitness Characteristics of High vs. Low Performers on An Occupationally Specific Physical Agility Test for Patrol Officers. The Journal of Strength \& Conditioning Research, 31(10), 2808-2815.

Dawes, J. J., Orr, R. M., Siekaniec, C. L., Vanderwoude, A. A. \& Pope, R. (2016). Associations Between Anthropometric Characteristics and Physical Performance in Male Law Enforcement Officers: A Retrospective Cohort Study. Annals of Occupational and Environmental Medicine, 28(1), 26.

Dempsey, P. C., Handcock, P. J. \& Rehrer, N. J. (2013). Impact of Police Body Armour and Equipment on Mobility. Applied Ergonomics, 44(6), 957-961.

Evans, R., Reynolds, K., Creedon, J. \& Murphy, M. (2005). Incidence of Acute Injury Related To Fitness Testing of US Army Personnel. Military Medicine, 170(12), 1005-1011.

Gendarmeria Nacional, Argentina (2021, January 08 . https://www.argentina.gob.ar/sites/default/files/informacion_relacionada_a_las_etapas_del_proceso_de _incorporacion_20jul20.pdf

Gendarmerie Nationale, France (2021, January 08). https://www.lagendarmerierecrute.fr/content/search?activeFacets\%5Binstallation\%3AInstallation\%5D= \&form $\% 5 \mathrm{BSearchText} \% 5 \mathrm{D}=\% \mathrm{C} 3 \% 89$ preuve $\% 20$ Physique $\% 20$ Gendarmerie $\% 20 \&$ form $\% 5 \mathrm{Bsave} \% 5 \mathrm{D}$ $=$ \&page $=1$

Gendarmerie Nationale, Senegal (2021, January 04). http://www.jo.gouv.sn/spip.php?article7958

Gendarmerie, Turkey (2021, January 08). http://www.tgf.gov.tr/tr/wp-content/uploads/2020/07/2020-Yili-JSGFOgrenci-Basvuru-Kilavuzu.pdf

Grant, S., Corbett, K., Amjad, A. M., Wilson, J. \& Aitchison, T. (1995). A Comparison of Methods of Predicting Maximum Oxygen Uptake. British Journal of Sports Medicine, 29(3), 147-152.

$\begin{array}{llll}\text { Guardia Civil, Spain (2021, January } & \text { 08). }\end{array}$ https://www.guardiacivil.es/es/institucional/serguacivil/ingresogc/ingresogc2.html\#temario.

$\begin{array}{lllll}\text { Guarda Nacional } & \text { Republicana, Portugal } & \text { (2021, } & \text { January }\end{array}$ https://dre.pt/home//dre/141382369/details/maximized

House PB. Amnesty International UK: Annual Report 2015.

Jandarmeria, Romania (2021, January 04). http://www.jandarmeriafalticeni.ro/aptitudinifizice.php

Kayihan, G., Özkan, A., Köklü, Y., Eyuboğlu, E., Akça, F., Koz, M. \& Ersöz, G. (2014). Comparative Analysis of the 1-mile Run Test Evaluation Formulae: Assessment of Aerobic Capacity in Male Law Enforcement Officers Aged 20-23 Years. International Journal of Occupational Medicine and Environmental Health, 27(2), 165-174. 
Knapik, J. J., Darakjy, S., Hauret, K. G., Canada, S., Scott, S., Rieger, W., ... \& Jones, B. H. (2006). Increasing the Physical Fitness of Low-Fit Recruits before Basic Combat Training: An Evaluation of Fitness, Injuries, and Training Outcomes. Military Medicine, 171(1), 45-54.

Knapik, J. J., Harman, E. A., Steelman, R. A. \& Graham, B. S. (2012). A Systematic Review of The Effects of Physical Training on Load Carriage Performance. The Journal of Strength \& Conditioning Research, 26(2), 585-597.

Knapik, J. J., Hauret, K. G., Arnold, S., Canham-Chervak, M., Mansfield, A. J., Hoedebecke, E. L. \& McMillian, D. (2003). Injury and Fitness Outcomes During Implementation of Physical Readiness Training. International Journal of Sports Medicine, 24(05), 372-381.

Knapik, J. J., Sharp, M. A., Canham-Chervak, M., Hauret, K., Patton, J. F. \& Jones, B.H. (2001). Risk Factors for Training-Related Injuries Among Men and Women in Basic Combat Training. Med Sci Sports Exerc, 33: $946-54$

Koninklijke Marechaussee, The Netherlands (2021, January 10). https://werkenbijdefensie.nl/training

Kraschnewski, J. L., Sciamanna, C. N., Poger, J. M., Rovniak, L. S., Lehman, E. B., Cooper, A. B., ... \& Ciccolo, J. T. (2016). Is Strength Training Associated With Mortality Benefits? A 15 Year Cohort Study of US Older Adults. Preventive Medicine, 87, 121-127.

Marins, E. F., Cabistany, L., Farias, C., Dawes, J. \& Del Vecchio, F. B. (2020). Effects of Personal Protective Equipment on Metabolism and Performance During An Occupational Physical Ability Test for Federal Highway Police Officers. The Journal of Strength \& Conditioning Research, 34(4), 1093-1102.

Marins, E. F. \& Del Vecchio, F. (2017). Health's Patrol Program: Health Indicators from Federal Highway Policemen. Scientia Medica, 27(2), 25855

Marins, E. F., David, G. B. \& Del Vecchio, F. B. (2019). Characterization of The Physical Fitness of Police Officers: A Systematic Review. The Journal of Strength \& Conditioning Research, 33(10), 2860-2874.

Molloy, J. M., Feltwell, D. N., Scott, S. J. \& Niebuhr, D. W. (2012). Physical Training Injuries and Interventions for Military Recruits. Military Medicine, 177(5), 553-558.

National Council of the General Commanders of the Military Police and Military Fire Corps, Brazil (2021, January 09). https://www.pm.pa.gov.br/taf.html

National Guard, Ukraine (2021, January 10). https://ngu.gov.ua/ua/pryyom-na-viyskovu-sluzhbu

Ozkaya, O., Balci, G. A., As, H., Cabuk, R. \& Norouzi, M. (2020). Grey Zone: A Gap Between Heavy and Severe Exercise Domain. The Journal of Strength \& Conditioning Research.

Pope, R. P., Herbert, R., Kirwan, J. D. \& Graham, B. J. (1999). Predicting Attrition in Basic Military Training. Military Medicine, 164(10), 710-714.

Sage, G. H. \& Loudermilk, S. (1979). The Female Athlete and Role Conflict. Research Quarterly. American Alliance for Health, Physical Education, Recreation and Dance, 50(1), 88-96.

Sarah, J., Gribbin, T. C., Lisman, P., Murphy, K. \& Deuster, P. A. (2017). Systematic Review of The Association Between Physical Fitness and Musculoskeletal Injury Risk: Part 2-Muscular Endurance and Muscular Strength. The Journal of Strength \& Conditioning Research, 31(11), 3218-3234.

Sherrard, J., Lenne, M., Cassell, E., Stokes, M. \& Ozanne-Smith, J. (2004). Injury Prevention During Physical Activity in the Australian Defence Force. Journal of Science and Medicine in Sport, 7(1), 106-117.

Shusko, M., Benedetti, L., Korre, M., Eshleman, E. J., Farioli, A., Christophi, C. A. \& Kales, S. N. (2017). Recruit Fitness As A Predictor of Police Academy Graduation. Occupational Medicine, 67(7), 555-561.

Taylor, N. A., Peoples, G. E. \& Petersen, S. R. (2016). Load Carriage, Human Performance, and Employment Standards. Applied Physiology, Nutrition, and Metabolism, 41(6), S131-S147. 